\title{
Meat Quality of Rainbow Trout (Oncorhynchus Mykiss) from the Bistrișorii Valley Trout Farm, Alba County
}

\author{
Andrada IHUȚ ${ }^{1}$, Camelia RĂDUCU ${ }^{1}$, Daniel COCAN $^{1}$, Călin LAȚIU ${ }^{1}$, Paul UIUIU ${ }^{1}$, \\ Vioara MIREŞAN ${ }^{1 *}$ \\ ${ }^{1}$ Faculty of Animal Science and Biotechnologies, University of Agricultural Sciences and Veterinary \\ Medicine Cluj-Napoca, 3-5 Mănăştur Street, 400372, Romania \\ *corresponding author, e-mail: vmiresan@yahoo.com; vioara.miresan@usamvcluj.ro
}

Bulletin UASVM Animal Science and Biotechnologies 75(1)/ 2018

Print ISSN 1843-5262; Electronic ISSN 1843-536X

DOI:10.15835/buasvmcn-asb: 003617

\begin{abstract}
Fish meat represents a great energy source in human nutrition, due to its content in high biological value protein, lipids which contain omega acids and minerals. The chemical composition of fish meat can be influenced by several factors such as: species, administered feed, environment, age and spawning period. The aim of this research was to analyse the chemical composition of the rainbow trout meat reared in the fishery Valea Bistrişorii, in a classical system. The determination of water (W \%), minerals (M \%) and dry matter (DM \%) content was performed by calcination. The crude fat (CF \%) was determined by Soxhlet method and crude protein (CP \%) by the Kjeldahl method. Analysing the chemical composition of the rainbow trout meat, the following values were obtained: $\mathrm{W}=73.60 \pm 0.23 \% ; \mathrm{DM}=26.40 \pm 0.14 \% ; \mathrm{CP}=18.21 \pm 0.14 \% ; \mathrm{CF}=6.87 \% ; \mathrm{M}=1.32 \%$. The obtained data offers useful information of meat chemical composition for selection of future breeders and improving the rainbow troutraised in the Bistrişorii Valley.
\end{abstract}

Keywords: chemical composition, crude fat, minerals, crude protein

\section{INTRODUCTION}

Fish meat has always been an important food source in human nutrition. Over time, due to climate change, pollution and overfishing, a major decline in global fish stocks has occurred. For these reasons, as well as many others, the specialists have reoriented on the development of continental fish farming. In fact, statistical data show an increase in aquaculture production compared to marine and oceanic capture. Fish species from the Salmonidae family have always shown an increased interest for consumers, due to their organoleptic characteristics and increased biological value of fish meat (Coroian et al., 2015), respectively the balanced content in amino acids and polyunsaturated fatty acids (Celik et al., 2008). The quality of fish meat from aquaculture depends on several factors, among which: the quality of feed and the feeding program, physicochemical parameters of the water and rearing technology(population density) (Cocan et al., 2015; Nistor et al., 2014). Rainbow trout meat chemical composition can be improved by selection of the breeders to satisfy the highest requirements of the consumer.

\section{MATERIALS AND METHODS}

This study was conducted during June-July 2015, in the research laboratories of UASVM Cluj-Napoca, Faculty of Animal Science and Biotechnologies. The chemical composition of fish meat was determined for 15 specimens of rainbow trout (Oncorhynchus mykiss) weighing between 250-300 g, reared in the Valea Bistrișorii trout farm, Alba County. Determination of the water content (W\%) was made by drying in 
Table 1. Meat chemical composition in rainbow trout (Oncorhynchus mykiss)

\begin{tabular}{|c|c|c|c|c|}
\hline \multirow{2}{*}{ SPECIFICATION } & \multirow{2}{*}{$\mathbf{n}$} & \multicolumn{3}{|c|}{ VARIABLES } \\
\hline & & $X \pm s x$ & $\mathbf{s}$ & V\% \\
\hline Water \% & & $73.60 \pm 0.14$ & 0.54 & 0.73 \\
\hline Dry matter \% & & $26.40 \pm 0.14$ & 0.54 & 2.05 \\
\hline Crude protein \% & 15 & $18.21 \pm 0.14$ & 0.54 & 2.97 \\
\hline Crude fat $\%$ & & $6.87 \pm 0.13$ & 0.51 & 7.36 \\
\hline Minerals \% & & $1.32 \pm 0.01$ & 0.03 & 2.41 \\
\hline
\end{tabular}

oven samples at $100^{\circ} \mathrm{C}-105^{\circ} \mathrm{C}$ for $2-4$ hours (mandatory in case of litigation) (Iurca, 2006). The dry matter content (DM \%) was determined by the percentage difference of the analysed mass sample and total water content witch was determined by dry in oven. The determination of crude fat (CF $\%$ ) was done by extraction with organic solvent (petroleum ether) using the Soxhlet apparatus (Șara, 2006).

Crude protein (CP \%) was determinate by Kjeldahl method (Șara, 2006) and mineral substances (M \%) was done by calcining the analysedsamples at $600^{\circ} \mathrm{C}$ for 5 hours. The statistical data was analysed with the GraphPad Prism 6 program.

\section{RESULTS AND DISCUSSION}

The fish meat water composition (W\%) was between $72.10 \%-74.20 \%$ with an average of $73.60 \pm 0.14 \%$. The dry matter (DM\%) was $26.40 \pm 0.14 \%$. The content of protein from fish meat is superior to pork, beef or mutton. In our research crude protein $(\mathrm{CP} \%)$ content was between $17.39 \%-18.88 \%$ with an average of 18.21 $\pm 0.14 \%$ (Tab.1). The values obtained are higher than the quoted values by Cocan (2011), 17.10 $\pm 0.07 \mathrm{CP} \%$ and González et al., (2004), 16.04 $\mathrm{CP} \%$ and a little lower than the limitsquoted by Banu (2010) for Salmo trutta fario, 18.8-19.1 $\mathrm{CP} \%$. The crude fat $\mathrm{CF} \%$ was $6.87 \pm 0.13 \%$ higher than the quoted values by Celiket al., (2008) of $4.43 \%$. Due to the fact that rainbow trout is an ameliorated species, suitable for captivity rearing, less active then wild specimens, leads to more fat deposits in the meat instead of muscle fibers. The rainbow trout meat minerals values were between $1.27 \%-1.37 \%$ with an average of
$1.32 \pm 0.01 \%$, the values are higher than the quoted by Coroian et al., (2015) 1.27\%and lower than the limits quoted by Celik et al., (2008) of $1.36 \%$. The fish meat minerals values can be influenced and because of the food fodder composition.

\section{CONCLUSIONS}

The rainbow trout population reared in the Bistrişorii Valley trout farm has higher meat quality.Depending on the consumer's requirement (fish meat with higher or lower fat) the fish meat composition can be improved with a goodfodder (feeding density) and rearing conditions (population density). The rainbow trout specimens (Oncorhynchus mykiss) reared in the Bistrişorii Valley trout farm have adequate organoleptic characteristics due to the feed (Aqua Garant), the water quality (free from upstream pollution) and the rearing conditions.

Acknowledgments. This paper was published under the frame of European Social Fund, Human Resources Development Operational Programme 2007-2013, project no. POSDRU/159/1.5/S/132765.

\section{REFERENCES}

1. Banu C, Bărăscu E, Stoica A, Dorin S (2010). Peștele aliment funcţional. Ed. Agir Bucureşti.

2. Celik M., Ğokçe MA, Usta NB, Küçükgülmez A, Taşbozan O, Tabakoğlu SS (2008). Nutritional quality of rainbow trout (Oncorhynchus Mykiss) caught from the Atatürk dam lake in Turkey. Journal of Muscle Foods 19:50-61.

3. Cocan D (2011). Particularităţi morfo-fiziologice ale Păstrăvului curcubeu în diferite sisteme de creştere şi exploatare. Teză de doctorat USAMV, Cluj Napoca.

4. Cocan D, Mireșan V, Coșier V, Ruxanda F, Rus V, Miclăuş V (2015). Lipid accumulation in rainbow trout (Oncorhynchus mykiss) muscle cells, reared in superintesive system. Annals of R.S.C.B., 2: 55 - 59. 
5. Coroian CO, Coroian A, Răducu CM, Atodiresei AC, Cocan DI Mireşan V (2015). Influence of various fat levels on meat quality in rainbow trout (Oncorhynchus mykiss) and brook trout (Salvelinus fontinalis). AACL BiofluxAquaculture, Aquarium, Conservation \& Legislation, 8:1065-1071.

6. González FE, Linares G, Villarino-Rodriguez MC, Arias AGMT, Garcia-Fernandez MC (2004). Evaluation of the microbiological safety and sensory quality of rainbow trout (Oncorhynchus mykiss) processed by the sous vide method. Food Microbiology, 21:193-201.
7. Iurca IM (2006). Procesarea și controlul calității produselor acvacole. Ed. Academic Press, Cluj-Napoca.

8. Nistor CE, Pagu BI, Albu A, Păsărin B (2014). Study of meat physical-chemical composition of three trout breeds farmed in salmonid exploitations from Moldova. Scientific Papers, Banat's University of Agricultural Sciences and Veterinary from Timisoara, Animal Science and Biotechnologies, 47:190-195.

9. Șara A, (2006). Nutreţurile și utilizarea lor în hrana animalelor, Ed. Risoprint Cluj Napoca. 